\title{
Water-Table Altitude Near The Brookhaven National Laboratory, Suffolk County, New York, In August 1995
}

\author{
U.S. Department of the Interior-U.S. Geological Survey
}

\section{Introduction}

The U. S. Geological Survey (USGS), in cooperation with Brookhaven National Laboratory Office of Environmental Restoration (BNL-OER), is conducting a long-term project to investigate the hydrogeologic framework and to monitor ground-water levels in the 300 square-mile area of central Suffolk County that surrounds BNL (see inset map, p. 3). This fact sheet depicts the water-table configuration in that area during August 1995. The water-table altitude in the study area during March 1995 is presented in Scorca and others (1996); water-table altitudes in this part of Long Island in previous years are depicted in Warren and others (1968), Krulikas (1986), Doriski (1987), and Wexler and Maus (1988).

Central Suffolk County is underlain by 800 to 1,800 feet of Cretaceous- to Pleistocene-aged unconsolidated sediments that overlie a southward dipping bedrock surface (Smolensky and others, 1989).

Throughout most of Long Island, the water table lies within the upper glacial aquifer (the uppermost hydrogeologic unit), which ranges from 120 to 230 feet thick in the BNL area and consists of fine to coarse sand and gravel but also contains silty and clayey zones. The average horizontal hydraulic conductivity of the upper glacial aquifer on Long Island has been estimated to be about 270 feet per day (Smolensky and others, 1989), but aquifer tests conducted at the BNL site by Warren and others (1968) indicate the hydraulic conductivity at the site to be lower - about 180 feet per day. Additional information about Long Island's geologic units is presented in Suter and others (1949), Jensen and Soren (1974), Smolensky and others (1989), and de Laguna (1963).

\section{Water-Level Measurement}

Water levels in all observation wells shown in figure 2 were measured by the wetted-steel-tape and electric-tape methods, which are accurate to one-hundredth of a foot. All wells shown are screened in the upper glacial aquifer. Several of these are clustered wells, which are closely spaced wells completed at different depths.

\section{Hydrologic Conditions}

Annual precipitation for each year from 1991 through 1995 at the Upton precipitation station (fig. 2) was below the 1949-95 average (48.04 inches: fig. 1); during 1995 it was 39.40 inches, the lowest since 1985. Precipitation and ground-water levels during August 1995 were substantially below long-term averages. The precipitation for August 1995 ( 0.54 inches) was the lowest ever recorded for August at the Upton station. Monthly precipitation values from December 1994 through July 1995 at the Upton station were also below the long-term monthly averages. This extremely dry weather was a factor in several major brush fires in the region.
Hydrographs of wells S5517 and S6431 (fig. 1) depict water levels from 1980 through August 1995. Both wells are on the BNL site and have been monitored regularly since 1953; their long-term average water levels are 40.7 and 44.0 feet above sea level, respectively. and their long-term monthly averages for August are 41.0 and 43.2 feet above sea level, respectively. Water levels in these wells during August 1995 were about 2.4 and 3.0 feet below long-term monthly average for their periods of record, respectively.

The sparse rainfall during August 1995 produced almost no runoff; thus, Long Island streamflow at this time consisted almost entirely of base flow - the discharge of ground water to stream channels. The declining ground-water levels caused a decrease in base flow of the streams. The USGS has monitored the flow of the Peconic and Carmans Rivers (fig. 2) since 1942. Mean discharges for August during the period of record are 28.5 and 23.0 cubic feet
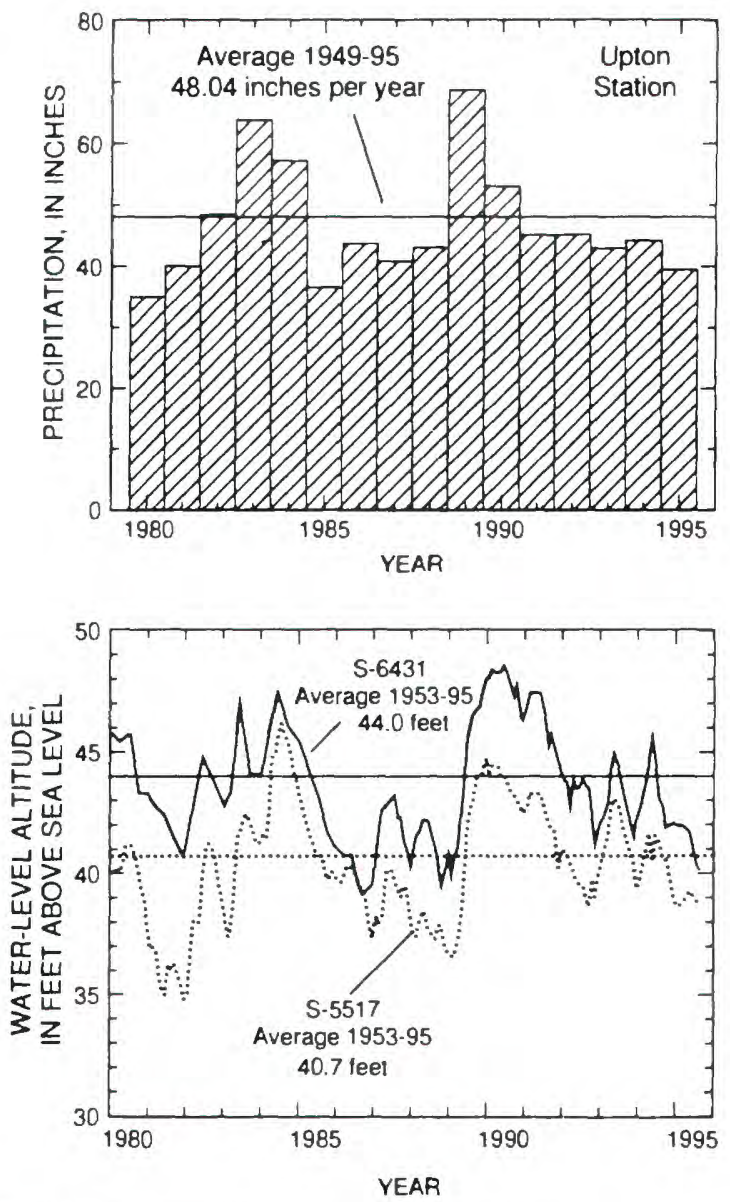

Figure 1. Precipitation and water-table altitude at Brookhaven National Laboratory, Suffolk County, N.Y. A. Annual precipitation at Upton station, 1980-95. B. Water levels in wells S5517 and S6431, January 1980 through August 1995. (Locations are shown in fig. 2.) 

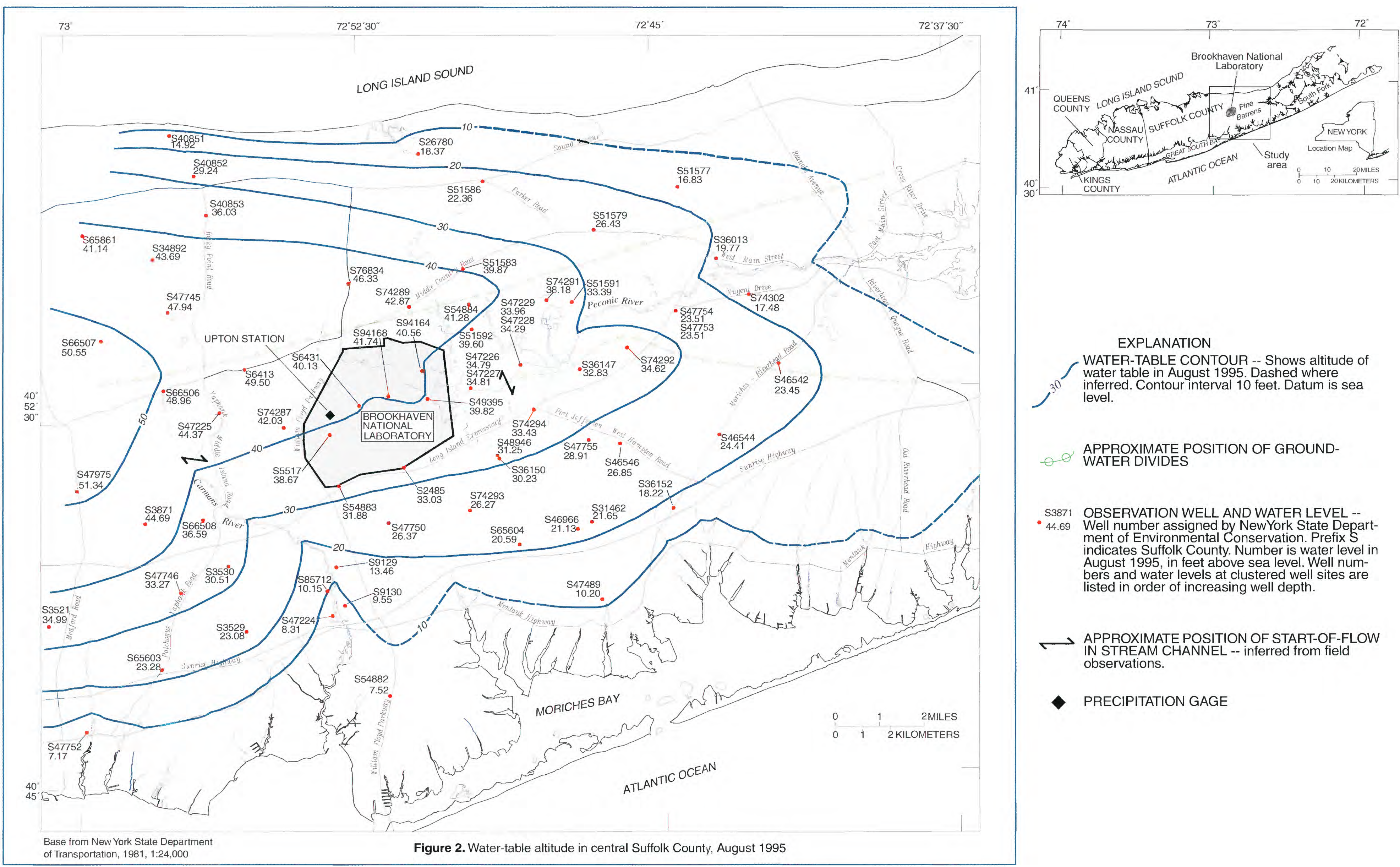

\section{EXPLANATION}

WATER-TABLE CONTOUR -- Shows altitude of water table in August 1995. Dashed where inferred. Contour interval 10 feet. Datum is sea level. APPROXIMATE POSITION OF GROUND-
WATER DIVIDES

S3871 OBSERVATION WELL AND WATER LEVEL -Well number assigned by NewYork State Department of Environmental Conservation. Prefix
indicates Suffolk County. Number is water level in August 1995, in feet above sea level. Well numbers and water levels at clustered well sites are listed in order of increasing well depth.

$\longrightarrow$ APPROXIMATE POSITION OF START-OF-FLOW N STREAM CHANNEL - inferred from field observations.

- PRECIPITATION GAGE 
per second $\left(\mathrm{ft}^{3} / \mathrm{s}\right)$, respectively. Monthly mean discharges of 12.8 and $11.8 \mathrm{ft}^{3} / \mathrm{s}$ at the two streams for August 1995 (Spinello and others, 1996) were close to the record low monthly mean discharges for August ( 10.8 and $\left.10.5 \mathrm{ft}^{3} / \mathrm{s}\right)$.

Between storms, the flowing reach of a stream on Long Island begins at the point at which the water table intersects the stream channel, allowing ground water to enter the stream as base flow. This point (the start-of-flow) represents the altitude of the surrounding water table and moves upstream or downstream in response to water-table fluctuations. In the hydrologic system of Long Island, the flowing part of a stream channel during periods of no storm runoff generally is a ground-water discharge area and is considered to be under gaining-stream conditions. Start-of-flow locations observed during August 1995 are indicated in figure 2.

\section{Water-Table Configuration}

The water table is highest in the northern part of central Suffolk County and generally slopes downward toward the shores. The discharge of ground water to the Peconic and Carmans Rivers locally affects the water-table configuration and results in the bending of water-level contours in an upstream direction (fig. 2). Water levels within the BNL site are also affected by pumping wells, recharge basins, and by discharge from the sewage-treatment facility to the Peconic River. Water levels at clustered wells S47228 and S47229 (along the Peconic River) indicate an upward vertical ground-water flow gradient; the head in the deeper well is 0.33 feet higher than that in the shallower well.

The position of a ground-water divide depends on the watertable configuration and may be affected by the location of the startof-flow in streams. North of the main ground-water divide within Long Island's upper glacial aquifer, ground water flows northward and discharges to Long Island Sound; ground water to the south of the divide flows southward and discharges to south-shore streams, the Peconic River, Great South Bay, and the Atlantic Ocean.

A second ground-water divide originates near the Peconic River's start-of-flow and extends eastward toward the South Fork. Water north of this divide enters the Peconic River as base flow. The Peconic River did not affect the water-table configuration directly beneath BNL during August 1995, however, because its start-offlow at that time was estimated to be about 1.2 miles east of the site.

\section{Acknowledgments}

Thanks are extended to William Gunther, manager of BNLOER, for his assistance and cooperation during this project. Appreciation is also expressed to Victor Cassella of BNL's

\section{For more information contact:}

Subdistrict Chief

U.S. Geological Survey

2045 Route 112, Bldg. 4

Coram, New York 11727

(516) 736-0783
Department of Applied Science, Oceanographic and Atmospheric Sciences, for providing precipitation data from the Upton station.

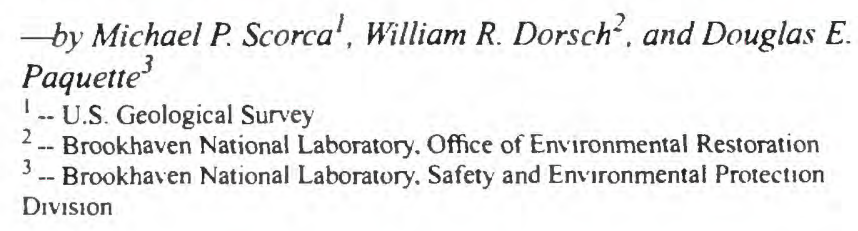

\section{References Cited}

de Laguna, Wallace, 1963, Geology of Brookhaven National Laboratory and vicinity, Suffolk County, New York: U.S. Geological Survey Bulletin 1156-A. 35 p.

Doriski, T.P., 1987, Potentiometric surface of the water-table. Magothy, and Lloyd aquifers on Long Island, New York, in 1984: U.S. Geological Survey Water-Resources Investigations Repon 86-4189, 4 pl., scale 1:125.000.

Jensen, H.M., and Soren, Julian, 1974. Hydrogeology of Suffolk County, Long Island. New York: U.S. Geological Survey Hydrologic Investigation Atlas HA-501, 2 sheets, scale 1:250,000.

Krulikas, R. K., 1986, Hydrologic appraisal of the Pine Barrens, Suffolk County, New York: U.S. Geological Survey Water Resources Investigations Repor 84-4271, $53 \mathrm{p}$.

Scorca, M. P., Dorsch, William R., and Paquette, Douglas E., 1996, Water-table altitude near the Brookhaven National Laboratory, Suffolk County, New York, in March 1995: U S. Geological Survey Fact Sheet FS-128-96, 4 p.

Smolensky, D.A., Buxton, H.T., and Shernoff, P.K., 1989, Hydrologic framework of Long Island, New York: U.S. Geological Survey Hydrologic Investigations Atlas HA-709, 3 sheets, scale 1:250,000.

Spinello, A.G., Busciolano, R.J., and Winowitch, R.B., and Eagen, V.K., 1996, Water Resources Data, New York. Water year 1995, volume 2--Long Island: U.S. Geological Survey Water Data Report NY-95-2 (published annually), $247 \mathrm{p}$.

Suter, Russell, de Laguna, Wallace, and Perlmutter, N.M., 1949, Mapping of geologic formations and aquifers of Long Island, New York: New York State Water Power and Control Commission Bulletin GW-18, 212 p.

Warren, M.A., de Laguna, Wallace, and Lusczynski, N.J., 1968, Hydrology of Brookhaven National Laboratory and vicinity, Suffolk County, New York: U.S. Geological Survey Bulletin 1156-C, $127 \mathrm{p}$.

Wexler, E.J., and Maus, P.E., 1988, Ground-water flow and solute transport at a municipal landfill site on Long Island, New York-part 2, simulation of ground-water flow: U.S. Geological Survey Water-Resources Investigations Report 86-4106, 44 p.

Additional earth science information can be found by accessing the USGS "Home Page" on the World Wide Web at "http://water.usgs.gov", or by calling 1-800-H2O-9000 (1-800-426-9000).

For more information on all USGS reports and products (including maps, images, and computerized data), call

1-800-USA-MAPS. 